\title{
COMPARATIVE TOXICITY OF THREE NOVEL BIOTIC COMPOUNDS, SPINOSAD PYRIDALYL AND RADICAL IN RELATIVE TO A CONVENTIONAL INSECTICIDE, LANNATE AGAINST THE FIELD AND LABORATORY STRAIN OF THE SECOND AND FOURTH INSTAR LARVAE OF COTTON LEAFWORM, Spodoptera Littoralis (BOISD.)
}

\author{
ELHAM F. ABDEL-RAHIM, A. M. AZAB, M. M. ALI, G. A. MORSI AND \\ MAHASEN A. AHMED
}

Plant Protection Res. Institute, ARC, Dokki, Giza

(Manuscript received 17 November 2008)

\begin{abstract}
The toxic activity of three novel compounds( Pyridayl, Radical, Spinosad) and conventional insecticide( Lannate)against the second and fourth instars of the Lab. and Field strains of Spodoptera littoralis. was evaluated under laboratory conditions through determination their LC50 values. ' Radical was the most toxic one against both of $2^{\text {nd }}$ and $4^{\text {th }}$ instar larvae of the lab. and field strains . The $\mathrm{LC}_{50}$ values were $1.1,2.7$ and $1.95,4.4 \mathrm{ppm}$ for both second and fourth instar larvae of the two lab. and field strains, respectively. Pyridalyl was the second one with the $\mathrm{LC}_{50}$ values of $1.8,5$ and $6.2,9.4 \mathrm{ppm}$ for the two instars of both strains, respectively. Lannate was the third one, its $\mathrm{LC}_{50}$ values were $3.9,6$ and $11,19 \mathrm{ppm}$ for both instars of the strains, respectively. While, Spinosad was the fourth one, its $\mathrm{LC}_{50}$ values were $21,62.5$ and 31.3 and $130 \mathrm{ppm}$ for both instars of the strains, respectively. All the treated larvae were biologically affected by the four tested compounds. The effect varied according to the strain, larval instar and tested compound. Therefore, the treated larvae were significantly affected and resulted in decreased pupation and adult emergence percentages. While, Pyridalyl treatment had the strongest effect in larval duration, pupal and adult malformations increase, adult fecundity ,fertility and longevity decrease in case of larval treatment of the two instars of both strains, and it had the highest effect in pupal duration increase and weight decrease in case of treatment of the second instar of the field strain with this compound, and it was effective against the sex ratios, it induced the males increase and females decrease, as respect to control, with the treatment of fourth instar of lab. strain. Whereas, Radical , had the greatest effect on adult fecundity and fertility with the of fourth instar treatment of field strain .Also it was effective against the pupal weight with the treated second instar of field strain and it had the highest effect on larval duration and adult malformations in case of the treatment of the second and fourth instars of lab strain .However, it had an adversely effect on the sex ratio (it caused males decrease and females increase) with the treatment of fourth instar of field strain. Spinosad had the highest effect on both adult fecundity and fertility with the treated fourth instar of field strain and it induced the strongest effect of adult malformations with the treatment of both instars of lab. strain , and it affect the sex ratio, lead to males increase and females decrease with the treatment of fourth instar of lab .strain. Lannate, had the highest effect on
\end{abstract}


434 COMPARATIVE TOXICITY OF THREE NOVEL BIOTIC COMPOUNDS , SPINOSAD PYRIDALYL AND

RADICAL IN RELATIVE TO A CONVENTIONAL INSECTICIDE, LANNATE AGAINST THE FIELD

AND LABORATORY STRAIN OF THE SECOND AND FOURTH INSTAR LARVAE

OF COTTON LEAFWORM, Spodoptera Littoralis (BOISD.)

pupal malformations with the larval treatment of both instars of both strains, and it was effective on pupal weight and adult malformations with the treatment of either second or second and fourth instar together of field strain ,also, it was effective on adult fecundity, fertility and longevity with the treated fourth instar of field strain and it had the strongest effect on larval duration with the treatment of the fourth instar of the lab. strain .

\section{INTRODUCTION}

The cotton leafworm, Spodoptera littoralis (Boisd) is one of the major pests that cause a considerable damage to many of the important vegetable and field crops in Egypt. The rising consumption of currently used insecticides in developing countries has led to a number of problems such as insect resistance, environmental pollution and the health hazards associated with pesticide residues. It is therefore necessary to complement our reliance on synthetic pesticides with less hazardous ,safe ,and biodegradable substitutes such as the biotic novel compounds: Spinosad, Pyridalyl and Radical. Spinosad played an important role in pests control and gets its name from the microbe that produces it, a soil-dwelling bacterium called Saccharopolyspora spinosa. Spinosad which represents a new class of insecticides that acting by a novel mode of action ( Thompson et al. 2000 )and possesses less risk than most insecticides to mammals, birds, fish, and beneficial insects, was used for control of Lepidoptera insects ( Temarak,2003a). Also , Pyridalyl is an insecticide of a novel chemical class (unclassified insecticides) with an unknown mode of action that causes loss of vigour and death within 2-3 hours in lepidopterous larvae and is effective in the control of lepidopterous pests and thrips in cotton and vegetables. Toxicity of pyridalyl to insect pest specie, Spodoptera litura, was evaluated in the laboratory( Shigeru et al.,2004 and Isayama et al.,2005). It active against the resistant strain of diamondback, Plutella xylostella $(\mathrm{L})$ and Heliothis virescens $(\mathrm{F})$ that are resistant to various insecticides. It also produces unique insecticidal symptoms, so it may have a different mode of action from other existing insecticides. Also, Radical, as a novel compound may be obtained from Streptomyces avermitilis was estimated as insecticide by Grove and Bovington(2008).The conventional insecticide, Lannate was used for the lepidopterous pests control (Kassem et al.,1986 ).

The aim of the present study is to compare the insecticidal efficacy of three novel compounds(Radical, Pyridalyl and Spinosad) in relative to the conventional insecticide (Lannate)against the second and fourth instar larvae of the field and laboratory strains of $S$. littoralis.. 


\section{MATERIALS AND METHODS}

\section{The Field strains}

Field strain egg masses of cotton leafworm (CLW) were collected from cotton fields at Sides Station Research , Beni-Suef during 2006-2007 cotton growing seasons at which CLW larvae have been exposed to field routine selection pressure of certain conventional insecticides that are usually applied every year from June to September. These insecticides were insect growth regulators, organophosphates (OPs) as Dursban and Tilton insecticides, pyrethroids (PYs) as Sumi- alpha ,biotic compounds as Spintor and Agerin . The egg-masses were collected during June and reared on castor bean leaves Ricinus communis (L.) under temp. ranged between $25-28 \mathrm{C}$ and $60-65$ $\%$ relative humidity until egg hatching. The obtained second and fourth instar larvae were used for bioassay tests.

\section{The laboratory strains}

The cotton leaf worm, $S$. littoralis was reared in the laboratory for several generations at room temp. ranged between $25-28 C^{\circ}$ and $60-65 \%$ R.H. Larvae were fed on castor bean leaves, Ricinus communis (L.) in a wide glass jars until pupation period and adults emergence. The newly emerged adults were mated inside glass jars and supplied with a piece of cotton wetted with $10 \%$ sugar solution as feeding source for the emerged moths and branches of Tafla (Nerium oleander L.) or castor bean leaves as an oviposition site (El- Defrawi et al.,1964). Egg masses were kept in plastic jars until hatching. The obtained second and fourth instar larvae were used for bioassay tests.

\section{2-Materials used}

2.1-Spinosad, the used spinosad ( $24 \% \mathrm{SC}$ )

Trade name: The insecticide was introduced by Dow Agro Sciences for control Lepidopterous pests in cotton under the trade name Tracer (Thompson et al., 1997). Chemical name : The name spinosad is derived from combining the characters Spinosyn A and D. The rate of application was $50 \mathrm{~cm}^{3} /$ fed

Empirical formula: Spinosyn A:C41H65NO10, Spinosyn D:C42H67NO10

Molecular weight $\quad$, Spinosyn A:731.98, Spinosyn D:745 


\section{Structure :}

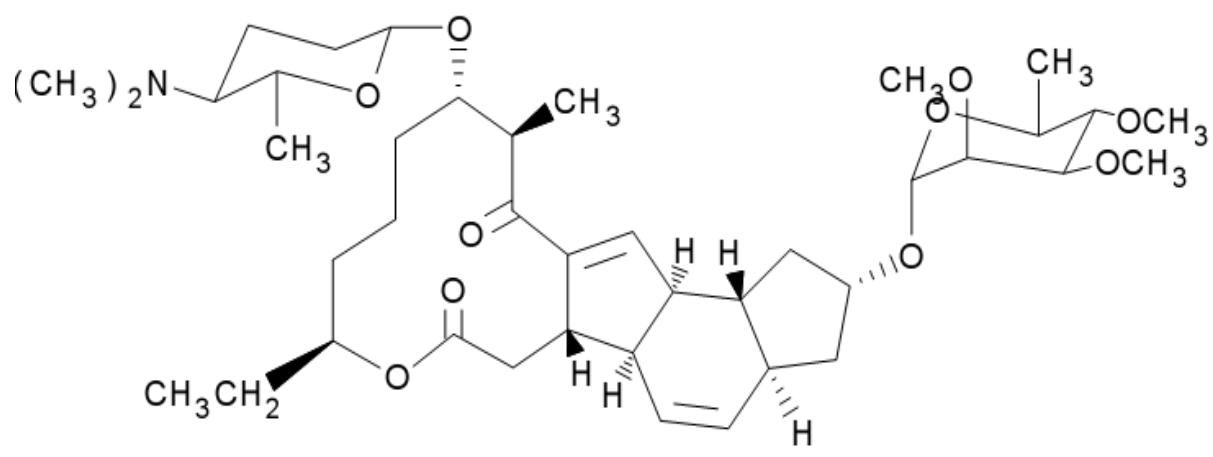

\section{spinosyn $A$}

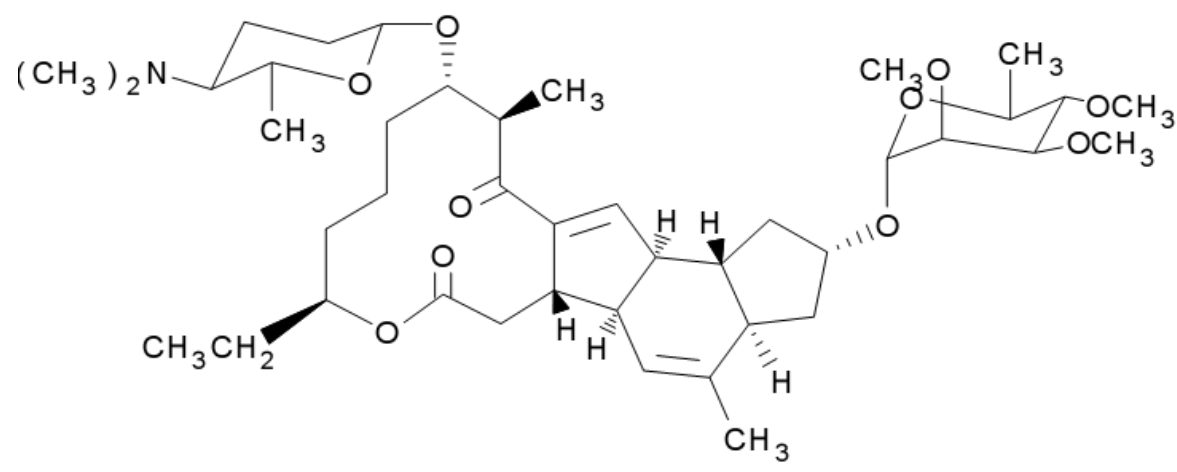

\section{spinosyn D}

2.2-Common name (ISO name) :Pyridalyl

Trade name: The insecticide was introduced by Valent USA

for control Lepidopterous pests in cotton under the trade name Pyridalyl (S-1812): The rate of application was $50-200 \mathrm{~g}$ ai/ha.

Chemical name: 2,6-Dichloro-4-(3,3-dichloroallyloxy)phenyl3[5(trifluoromethy) 2pyridyloxy]propyl ether

Molecular Formula: $\mathrm{C} 18 \mathrm{H} 14 \mathrm{Cl} 4 \mathrm{~F} 3 \mathrm{NO} 3$

Molecular Weight: 491.12 
Structure:

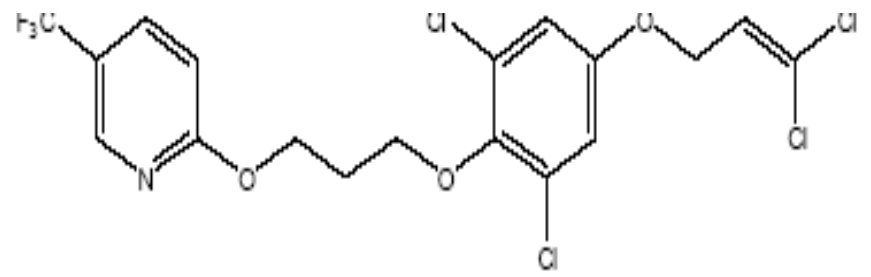

2.3-Common Name: Methomyl

Trade names: Lannate, Lanox 216, NuBait II, Nudrin, SD 14999

Chemical Name: S-Methyl-N-[(methylcarbamoyl)oxy]-thioacetimidate

Molecular formula: $\mathrm{C} 5 \mathrm{H} 10 \mathrm{~N} 2 \mathrm{O} 2 \mathrm{~S}$

Molecular weight: 162.20

\section{Structure:}

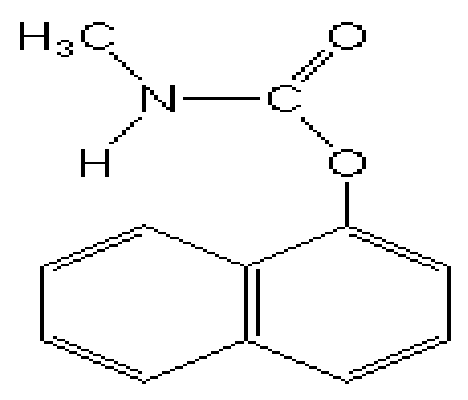

\section{4-Radical (0.5\%E.S)}

Source: It 's avermectin derivatives consist of combination of Methylamine and averment, El- Aserah company.

Averment: which can be obtained from Streptomyces avermitilis are referred to as A1a, A1b, A2a, A2b, B1a, B1 b, B2a and B2b. The compounds referred to as "A" and "B" have a methoxy radical and an $\mathrm{OH}$ group, respectively, in the 5-position. The "a" series and the "b" series are compounds in which the substituent R1 (in position 25) is a sec-butyl radical and an isopropyl radical, respectively.

Molecular formula:C48 H72 014

Molecular weight: 873.1 


\section{structure}

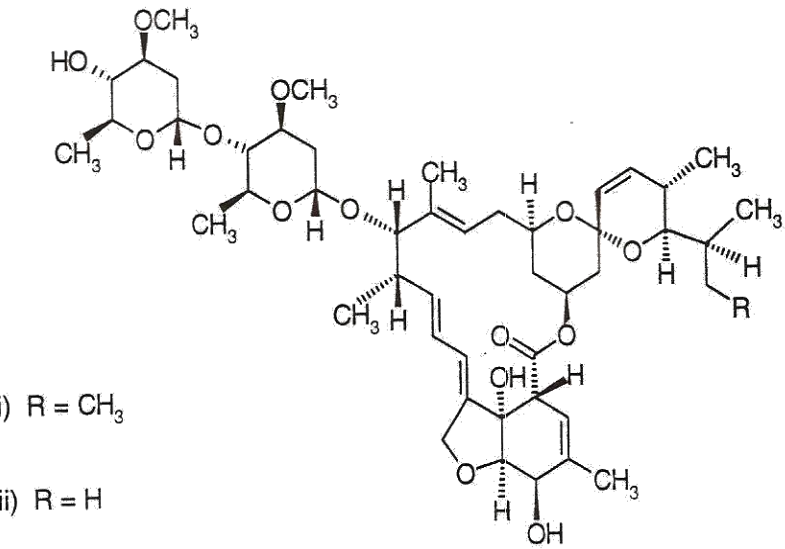

\section{3- Test procedures}

A series of different concentrations of each of the four tested compounds, Pyridalyl, Radical, Spinosad, and Lannate were prepared on the active ingredient basis (p.p.m)using water as a solvent for dilution . Both Pyridalyl and Radical were tested at 31.3, 15.6, 7.8, 3.9, 1.95 and $0.975 \mathrm{ppm}$, Spinosad was tested at 500, $250,125,62.5,31.3$ and 15.6ppm, Lannate was tested at $62.5,31.3,15.6,7.8,3.9$ and $1.95 \mathrm{ppm}$. The leaves of castor were dipped for 15 seconds in each concentration ,then left to dry in air current for about $1 \mathrm{hr}$. Also, castor leaves were dipped in only distilled water and used as control. About forty larvae in two replicates of each second and fourth instar larvae of both susceptible(laboratory) and resistant(field) strains for all treatments including the control were used. After 48h.,the treated leaves was replaced by another untreated ones and the larvae fed on it until the pupation .The jars were examined daily to determine the larval mortality. The different biological effects such larval and pupal duration, pupation and adults emergence percentage , pupal weight ,adult fecundity ,fertility ,longevity , sex ratio were determined at the LC50 values of the four compounds. Also ,the observed malformations were recorded and photographed.

\section{4-Statistical analysis}

The total percent of the larval mortality of the four tested compounds were recorded after $48 \mathrm{~h}$ of the larval feeding of both second and fourth instars of both susceptible and resistant strains of the four tested and corrected according to Abbott formula (Abbott, 1925). The data were then analyzed using the probit analysis (Finney, 1971) and the $\mathrm{LC}_{50}$ values of the four tested compounds were estimated for both susceptible and resistant strains. The different biological effects such larval and 
pupal duration , pupation and adult emergence percentage , adult fecundity , fertility , longevity , sex ratio were estimated at the $\mathrm{LC}_{50}$ values. The obtained data of the biology were statically calculated through Excel for windows computer program to determine the F-value, P-value and L.S.D ( least significant difference) at 0.05 or 0.01 freedom degrees.

\section{RESULTS AND DISCUSSION}

\section{1-Toxic effect}

Data illustrated in Table (1) showed the toxic effects of the four tested compounds, Pyridalyl , Radical , Spinosad and Lannate against the $2^{\text {nd }}$ and the $4^{\text {th }}$ instar larvae of both lab. and field strains of $S$. littoralis. Radical was the most toxic one against both $2^{\text {nd }}$ and $4^{\text {th }}$ instar larvae of both lab. and field strains. The $\mathrm{LC}_{50}$ values were $1.1,2.7$ and $1.95,4.4$ ppm for both second and fourth instar larvae of both lab. and field strains, respectively. While, Pyridalyl was the second one, the $\mathrm{LC}_{50}$ values were 1.8 , 5 and $6.2,9.4 \mathrm{ppm}$ for both instar larvae of both strains, respectively. Whereas, Lannate was the third one ,its $\mathrm{LC}_{50}$ values were 3.9, 6 and 11,19ppm for both instar larvae of both strains, respectively. While, Spinosad was the fourth one, its $\mathrm{LC}_{50}$ values were $21,62.5$ and 31.3 and $130 \mathrm{ppm}$ for both instar larvae of both strains, respectively.

Table 1. Insecticidal activity of Pyridalyl ,Radical, Spinosad and Lannate against the $2^{\text {nd }}$ and $4^{\text {th }}$ instar larvae of Lab. and Field strains of Spodoptera littoralis.

\begin{tabular}{|c|c|c|c|c|c|c|c|c|c|}
\hline \multirow[t]{3}{*}{ Treatment } & \multirow{3}{*}{ Strain } & \multicolumn{4}{|c|}{$2^{\text {nd }}$ instar } & \multicolumn{4}{|c|}{$4^{\text {th }}$ instar } \\
\hline & & \multirow{2}{*}{$\begin{array}{l}\text { LC50 } \\
\text { values } \\
\text { P.p.m }\end{array}$} & \multirow[t]{2}{*}{$\begin{array}{l}\text { Slope } \\
\text { function }\end{array}$} & \multicolumn{2}{|c|}{$\begin{array}{l}\quad 95 \% \\
\text { confidence limit }\end{array}$} & \multirow{2}{*}{$\begin{array}{l}\text { LC50 } \\
\text { values } \\
\text { P.p.m. }\end{array}$} & \multirow[t]{2}{*}{$\begin{array}{l}\text { Slope } \\
\text { function }\end{array}$} & \multicolumn{2}{|c|}{$\begin{array}{l}95 \% \\
\text { confidence limit }\end{array}$} \\
\hline & & & & Upper & Lower & & & Upper & Lower \\
\hline \multirow[t]{2}{*}{ Pyridalyl } & Lab. & 1.8 & 5.625 & 2.4 & 1.3 & 5 & 2.96 & 8.9 & 2.8 \\
\hline & Field & 6.2 & 2.95 & 10.5 & 3.7 & 9.4 & 2.63 & 10.3 & 8.6 \\
\hline \multirow[t]{2}{*}{ Radical } & Lab. & 1.1 & 2.19 & 1.7 & 0.7 & 2.7 & 2.934 & 2.97 & 2.46 \\
\hline & Field & 1.95 & 2.639 & 2.34 & 1.625 & 4.4 & 2.944 & 5.3 & 3.7 \\
\hline \multirow[t]{2}{*}{ Spinosad } & Lab. & 21 & 3.8 & 29.4 & 15 & 62.5 & 4.398 & 112.5 & 34.7 \\
\hline & Field & 31.3 & 4.63 & 62.4 & 15.7 & 130 & 4.565 & 195 & 86.7 \\
\hline \multirow[t]{2}{*}{ Lannate } & Lab. & 3.9 & 5.145 & 7.7 & 2 & 6 & 3.792 & 8.4 & 4.3 \\
\hline & Field & 11 & 3.365 & 18.7 & 6.5 & 19 & 3.9 & 41.8 & 8.6 \\
\hline
\end{tabular}

These results are in agreement with those obtained by Grove and Bovington (2008)who proved that the toxic activity of thiocyano radical through a ketomethylene group due to a lipoid soluble hydrocarbon residue gives rise to knock-down activity . They mentioned that the most active a-thiocyanoketones R.CO.CH$\cdot S C N$ and thiocyanoacetates R. O. CO. $\mathrm{CH}_{2}$. SCN are too irritant to the eyes and nose for inclusion in domestic fly-sprays. Also, Temarak(2007) showed that a radiant 12 SC (new generation) of Spinosad was 7 times stronger than Spintor 24 SC(old generation) to control of egg masses of Spodoptera littoralis in laboratory tests based on the LC50 
440 COMPARATIVE TOXICITY OF THREE NOVEL BIOTIC COMPOUNDS , SPINOSAD PYRIDALYL AND RADICAL IN RELATIVE TO A CONVENTIONAL INSECTICIDE, LANNATE AGAINST THE FIELD AND LABORATORY STRAIN OF THE SECOND AND FOURTH INSTAR LARVAE OF COTTON LEAFWORM, Spodoptera Littoralis (BOISD.)

values. He found that the radiant $12 \mathrm{SC}$ was 5 times stronger (it was active at 5.76 ppm) than the Spintor 24 SC (it was active at 28.8) in the field. This is similar to the results obtained by Hilal (2006)who tested the susceptibility of the field strain of third instar larvae of the cotton leaf worm, $S$. littoralis , as compared to the susceptible strain (S) at the lethal dose using the leaf dip method. He recorded that the LC50 values for field and susceptible strains were 43.691 and 10.037 ppm, respectively ,thus, he mentioned that the field strain was approximately 4.4-fold less sensitive than the lab. strain and suggests that spinosad is potentially important in the control of S. littoralis. Isayama et al.(2005) mentioned that the potency of pyridalyl was highly effective against all development stages (2nd to 6th instar larvae) of $S$. litura. Also, Shigeru et. a/(2004)observed the insecticidal action of pyridalyl at various dosages against $S$. litura larva .They found that larvae treated with $100 \mathrm{mg}$ or more/larva were killed within $6 \mathrm{hr}$ without any conspicuous symptoms, while the larvae treated with $25 \mathrm{mg}$ or less/larva and lower showed unique symptoms similar to scar burns at the site treated with pyridalyl after molting.They reported that such symptoms caused interference with metamorphosis, would suppress populations of $S$. litura even at lower dose rates. Cook et al. (2004)mentioned that the LC50 values of indoxacarb and pyridalyl for beet armyworm and fall armyworm exceeded the highest concentrations tested $(100-200 \mu \mathrm{g} / \mathrm{vial})$ in the adult vial test. They found that the dose-mortality values of indoxacarb and pyridalyl were higher than discriminating concentrations of cypermethrin, methomyl, profenofos, and endosulfan used in the adult vial test for monitoring tobacco budworm, Heliothis virescens (F.), and bollworm, Helicoverpa zea (Boddie). Also, Temarak (2003a) found that the field strain of the cotton leaf worm $S$.littoralis (known to be tolerant or resistant to most of the conventional insecticides )was to be more susceptible to Spinosad (Spintor,24 SC) than the laboratory strain (known as susceptible to conventional insecticides). Moulton et al.(1999)recorded the LC50 values of field populations ranged from 0.6 to $14 \mu \mathrm{g}$ spinosad/ml. They mentioned that field populations were 3.0 to 70 -fold less susceptible to spinosad than was a susceptible reference population. David et al.(1996)reported that the two formulations of Spinosad ,NAF-85 and NAF-127 were effective for control of black cutworm, Agrotis ipsilon, and Sod webworms, Agrostis palustris ,the NAF-85 was active at 15ppm, while NAF-127 was active at 8 ppm. Kassem et al.(1986)found that Methomyl (Nudrin 24.1\%L and Lannate90\%sp)was the most effective among the tested insecticides (Fenvalerate20\%, Fenitrothion 50\% , Carbaryl 85\%,Profenofos $72 \%$ and Dimilin 25\%) against $S$.littoralis , E.insulana and $P$. gossyipella .They mentioned that the mixtures of methomyl with Fenitrothion 
increased the initial mortality of $S$.littoralis and reduced infestation by $E$.insulana and P. gossyipella compared with treatments with either compound alone, while the methomyl mixtures with carbaryl, diflubezuron, profenofos or fenitrothion did not increase their efficacy compared with that of each insecticide alone.

\section{Latent effect}

\subsection{Larval and pupal periods}

Data in Tables (2 and 3) indicated that the larval treatment of both second and fourth instars of the field and laboratory strains with Pyridalyl at $\mathrm{LC}_{50}$ values had the strongest effect on the larval duration. The larval duration was highly significantly $(p<0.01)$ increased to average 25,21 and 23,18 days, of the two instars of both strains, respectively, as compared to $19,9.5$ and $16.3,8.8$ days, respectively, of control. Also the treatment of the lab .strain of the fourth instar with Radical and Lannate induced highly significant $(p<0.01)$ increase in the larval duration to average 21 and 22 days, respectively, as compared to 16.3 days of control. Whereas, the treatment of the second instar larvae of lab. and field strains with Radical, Spinosad, Lannate caused significant $(\mathrm{p}<0.05)$ increase in the larval duration to average $24.3,14.3,23.3,14$ and 24,14 days of both strains ,respectively, as compared to 19 and 9.5 days of control, respectively. The treatment of the fourth instar of the field and the lab. strains with Radical and Spinosad ,respectively, gave none significant increase in the larval duration, it averaged 12.3 and 19.3 days, as compared to control ( 8.8 and 16.3 days, respectively).

Tables ( 2 and 3 )showed that the treatment of the second instar of field strain with Pyridalyl had the highest effect on the pupal duration, it highly significantly $(p<0.01$ )increased the pupal duration to average 13.8 days, as compared to 8.8 days of the check. Also, the larval treatment of the fourth instar of same strain with the same compound induced significant $(p<0.05)$ increase in the pupal duration to average $12.3 d$, as compared to $7.5 d$ of control. However, the treatment of second instar of lab. and field strains with Radical significantly $(p<0.05$ )increased the pupal duration to average15.3 and 11.5 , respectively, as compared to10.5 and 8.8 of control. And the second and fourth instar of field strain treated with Spinosad induced significant $(p<0.05)$ increase in the pupal duration to average12.5 and 11.8 days, respectively, as compared to 8.8 and 7.5 days of control. Also, the treatment of the second and fourth instars of lab. strain with Lannate significantly $(p<0.05)$ increased the pupal duration to average 14 and 12.5 days, respectively, as compared to 10.5 and 10.3 days of control. Whereas the treatment of both second and fourth instars of the lab. strain with Pyridalyl gave none significant increase in the pupal duration to average 12.3 and 11 days, respectively, as compared to 10.5 and 10.3 days of control. 
442 COMPARATIVE TOXICITY OF THREE NOVEL BIOTIC COMPOUNDS, SPINOSAD PYRIDALYL AND RADICAL IN RELATIVE TO A CONVENTIONAL INSECTICIDE, LANNATE AGAINST THE FIELD AND LABORATORY STRAIN OF THE SECOND AND FOURTH INSTAR LARVAE OF COTTON LEAFWORM, Spodoptera Littoralis (BOISD.)

Also, the fourth instar of the lab. and field strains treated with Radical did not significantly increased the pupal duration, it averaged 11.5 and 9.8 , respectively, as compared to 10.3 and 7.5 days of control. And the second and fourth instar of the lab. strain treated with Spinosad recorded none significant increase in the pupal duration to average 13.3 and 10.8 days, respectively, as compared to 10.5 and 10.3 of control. Also, the second and fourth instar of the field strain treated with Lannate gave none significant $(p>0.05)$ increase in the pupal duration, it averaged 10.5 and 9.3 respectively ,as compared to that of the control (8.8 and 7.5 days ).

Table 2. Biological activity of Pyridalyl ,Radical, Spinosad and Lannate at their LC 50 values against the $2^{\text {nd }}$ instar larvae of Lab. and Field strains of Spodoptera littoralis.

\begin{tabular}{|c|c|c|c|c|c|c|c|c|}
\hline \multirow[t]{2}{*}{ Treatment } & \multirow[t]{2}{*}{ Strain } & \multirow{2}{*}{$\begin{array}{l}\text { Larval } \\
\text { duration } \\
\text { (days) } \pm \\
\text { SD }\end{array}$} & \multicolumn{2}{|c|}{ Pupation $\%$} & \multirow{2}{*}{$\begin{array}{l}\text { Pupal } \\
\text { duration } \\
\text { (days) } \pm \\
\text { SD }\end{array}$} & \multirow{2}{*}{$\begin{array}{l}\text { Pupal } \\
\text { weight } \\
(\mathrm{mg}) \\
\pm \text { S.D }\end{array}$} & \multicolumn{2}{|c|}{$\begin{array}{l}\% \text { Adult } \\
\text { emergence } \pm \text { S.D }\end{array}$} \\
\hline & & & $\begin{array}{l}\text { Normal } \\
\text { Mean } \pm \text { SD }\end{array}$ & $\begin{array}{c}\text { Malfo. } \\
\%\end{array}$ & & & Normal & $\begin{array}{c}\text { Malfo } \\
\% .\end{array}$ \\
\hline \multirow[t]{2}{*}{ Pyridalyl } & Lab. & $25 \pm 3.3^{* *}$ & $57.7 \pm 5^{* *}$ & $16.7^{* *}$ & $12.3 \pm 3 \mathrm{n} . \mathrm{s}$ & $258 \pm 39 *$ & $61 \pm 1.1 * *$ & $27.3^{* *}$ \\
\hline & Field & $21 \pm 6.3 * *$ & $60 \pm 8.2 * *$ & $15.4 * *$ & $13.8 \pm 1^{* *}$ & $160 \pm 35^{* *}$ & $63 \pm 0.3 * *$ & $26.2 * *$ \\
\hline \multirow[t]{2}{*}{ Radical } & Lab. & $24.3 \pm 2.5^{*}$ & $57 \pm 5^{* *}$ & $8.1^{*}$ & $15.3 \pm 3 *$ & $262 \pm 62 *$ & $52.7 \pm 3^{* *}$ & $20 * *$ \\
\hline & Field & $14.3 \pm 1.3^{*}$ & $58.3 \pm 4^{* *}$ & 6.7n.s. & $11.5 \pm 0.9^{*}$ & $182 \pm 51 * *$ & $60 \pm 11 * *$ & $8.1 *$ \\
\hline \multirow[t]{2}{*}{ Spinosad } & Lab. & $23.3 \pm 1.3^{*}$ & $51.7 \pm 9 * *$ & $6.3 \mathrm{n} . \mathrm{s}$ & $13.3 \pm 1 \mathrm{n} . \mathrm{s}$ & $267 \pm 59 *$ & $62.7 \pm 13^{* *}$ & $25.6^{* * *}$ \\
\hline & Field & $14 \pm 2.1^{*}$ & $53 . \pm 5^{* *}$ & $2.2 \mathrm{n} . \mathrm{s}$ & $12.5 \pm 3 *$ & $264 \pm 5.1 *$ & $66.3 \pm 4^{* *}$ & $10 *$ \\
\hline \multirow[t]{2}{*}{ Lannate } & Lab. & $24+2.8 *$ & $56.1+3 * *$ & $30 * *$ & $14 \pm 1.7 *$ & $291 \pm 32$ n.s & $58.4 \pm 12 * *$ & $10 *$ \\
\hline & Field & $14 \pm 1^{*}$ & $59 \pm 4.8 * *$ & $20^{* * *}$ & $10.5 \pm 1$ n.s & $184 \pm 116^{* *}$ & $64 \underline{ \pm} 8^{* *}$ & $20 * *$ \\
\hline \multirow[t]{2}{*}{ Control } & Lab. & $19 \pm 2$ & 100 & 0 & $10.5 \pm 0.5$ & $390 \pm 46$ & 100 & 0 \\
\hline & Field & $9.5 \pm 1.5$ & 100 & 0 & $8.8 \pm 0.4$ & $377 \pm 44$ & 100 & 0 \\
\hline \multirow[t]{2}{*}{ F value } & Lab. & 20.573 & 183.3 & 240.5 & 15.40 & 19.130 & 317.9 & 78.22 \\
\hline & Field & 73.9 & 139.6 & 70.56 & 46.837 & 32.624 & 126.2 & 186.6 \\
\hline \multirow[t]{2}{*}{$P$ value } & Lab. & 0.0297 & 0.00793 & 0.0193 & 0.0425 & 0.0231 & 0.00072 & 0.0073 \\
\hline & Field & 0.0227 & 0.00973 & 0.0026 & 0.00379 & 0.0288 & 0.00658 & 0.0053 \\
\hline \multirow[t]{2}{*}{ L.S.D.at.05 } & Lab. & 3.6 & 16.5 & 10.9 & 3.35 & 93.1 & 17.7 & 17.3 \\
\hline & Field & 4.4 & 17.0 & 0.725 & 2.88 & 130.9 & 14.6 & 5.4 \\
\hline \multirow[t]{2}{*}{ L.S.D.at.01 } & Lab. & 6.6 & 38.1 & 25.1 & 6.125 & 170.9 & 40.5 & 39.98 \\
\hline & Field & 8.1 & 39.2 & 1.675 & 5.28 & 240.5 & 33.6 & 12.5 \\
\hline
\end{tabular}

** = Highly Significant $(\mathrm{p}<0.01)$

S.D. $=$ Standard deviation

L.S.D. $=$ Least significant difference

n. $s=$ none Significant $(p>0.05)$

$$
\begin{gathered}
* \text { Significant }(\mathrm{p}<0.05) \\
\text { Malfo.= Malformation\% } \\
\text { Lab.=Laboratory strain }
\end{gathered}
$$

These results are in agreement with those obtained by Ahmed (2004) who mentioned that the larval period was elongated and the pupal period shorted for the new hatched larvae of pink and spiny bollworms(Laboratory and field strains) treated with the higher concentrations of Spinosad when compared with untreated larvae. Also, Ivan and Jesus (2000) demonstrated that cotton treated with Spinosad in Texas 
had fewer damaging bollworm and budworm larvae than plots treated with the other pesticides, and they suggested that Spinosad prevented small larvae from becoming larger and more damaging.

Table 3 . Biological activity of Pyridalyl ,Radical, Spinosad and Lannate at their LC $_{50}$ values against the $4^{\text {th }}$ instar larvae of Lab. and Field strains of Spodoptera littoralis

\begin{tabular}{|c|c|c|c|c|c|c|c|c|}
\hline \multirow[t]{2}{*}{ Treatment } & \multirow[t]{2}{*}{ Strain } & \multirow{2}{*}{$\begin{array}{l}\text { Larval } \\
\text { duration } \\
\text { (days) } \pm \\
\text { SD }\end{array}$} & \multicolumn{2}{|l|}{ Pupation $\%$} & \multirow{2}{*}{$\begin{array}{l}\text { Pupal } \\
\text { duration } \\
\text { (days) } \pm \\
\text { SD }\end{array}$} & \multirow{2}{*}{$\begin{array}{l}\text { Pupal } \\
\text { weight } \\
(\mathrm{mg}) \\
\pm \text { S.D }\end{array}$} & \multicolumn{2}{|c|}{$\begin{array}{l}\% \text { Adult } \\
\text { emergence }+ \text { S.D }\end{array}$} \\
\hline & & & $\begin{array}{l}\text { Normal } \\
\text { Mean } \pm \text { SD }\end{array}$ & $\begin{array}{l}\text { Malfo. } \\
\%\end{array}$ & & & Normal & $\begin{array}{l}\text { Malfo. } \\
\%\end{array}$ \\
\hline \multirow[t]{2}{*}{ Pyridalyl } & Lab. & $23 \pm 1.5^{* *}$ & $58 \pm 4.6^{* *}$ & $13.2 * *$ & $11+0.7 \mathrm{n} . \mathrm{s}$ & $316 \pm 63 \mathrm{n} . \mathrm{s}$ & $63+5 * *$ & $25^{* *}$ \\
\hline & Field & $18 \pm 5.6 * *$ & $60.7 \underline{\underline{ \pm}} 4.2 * *$ & $10.8^{* *}$ & $12.3 \pm 1.8 *$ & $181 \pm 50 \mathrm{n} . \mathrm{s}$ & $74 \pm 1.4 * *$ & $22 * *$ \\
\hline \multirow[t]{2}{*}{ Radical } & Lab. & $21 \pm 0.9 * *$ & $59.7 \pm 6.9^{* *}$ & $6.7 \mathrm{n} . \mathrm{s}$ & $11.5 \pm 2 \mathrm{n} . \mathrm{s}$ & $362 \pm 91 \mathrm{n} . \mathrm{s}$ & $57 \pm 1 * *$ & $8.3^{*}$ \\
\hline & Field & $12.3 \pm 2 \mathrm{n} . \mathrm{s}$ & $62+5^{* *}$ & 5.9n.s & $9.8 \pm 1.8 \mathrm{n} . \mathrm{s}$ & $229 \pm 41$ n.s & $75 \underline{25}$ *** & $4.8 \mathrm{n} . \mathrm{s}$ \\
\hline \multirow[t]{2}{*}{ Spinosad } & Lab. & $19.3 \pm 3 n . s$ & $63.3 \pm 10 *$ & $3 . \ln . \mathrm{s}$ & $10.8 \pm 0.4 \mathrm{n} . \mathrm{s}$ & $333 \pm 28 \mathrm{n} . \mathrm{s}$ & $67 \pm 1.5^{* *}$ & $23.1 * *$ \\
\hline & Field & $12.5 \pm 1.5^{*}$ & $68.3 \pm 8.5^{*}$ & $2.2 \mathrm{n} . \mathrm{s}$ & $11.8 \pm 3^{*}$ & $284 \pm 53$ n.s & $72 \pm * *$ & $3.3 \mathrm{n} . \mathrm{s}$ \\
\hline \multirow[t]{2}{*}{ Lannate } & Lab. & $22 \pm 2 * *$ & $57.3 \pm 5.3 * *$ & $18.7^{* * *}$ & $12.5 \pm 1.7 *$ & $355 \pm 34 n . s$ & $61 \pm 7 * *$ & $6.7 \mathrm{n} . \mathrm{s}$ \\
\hline & Field & $13.3 \pm 1.3 *$ & $64.7 \pm 6.9 *$ & $16^{* * *}$ & $9.3 \pm 1.3 \mathrm{n} . \mathrm{s}$ & $280 \pm 34$ n.s & $75 \underline{ \pm 1} * *$ & $24.5^{* *}$ \\
\hline \multirow[t]{2}{*}{ Control } & Lab. & $16.3+1.3$ & 100 & 0 & $10.3 \pm 0.4$ & $373+56$ & 100 & 0 \\
\hline & Field & $8.8 \pm 1.3$ & 100 & 0 & $7.5 \pm 0.9$ & $285 \pm 35$ & 100 & 0 \\
\hline \multirow[t]{2}{*}{ F value } & Lab. & 123.3 & 127.09 & 44.81 & 3.6793 & 3.04629 & 1936.05 & 280.5 \\
\hline & Field & 17.4 & 91.067 & 9.4205 & 84.08 & 3.3361 & 1816.59 & 130.4 \\
\hline \multirow[t]{2}{*}{$P$ value } & Lab. & 0.01573 & 0.0154 & 0.00156 & 0.05767 & 0.0487 & 0.00433 & 0.00648 \\
\hline & Field & 0.0384 & 0.01656 & 0.02048 & 0.01931 & 0.5217 & 0.00133 & 0.00421 \\
\hline \multirow[t]{2}{*}{ L.S.D.at.05 } & Lab. & 2.87 & 19.5 & 1.95 & 3.6 & 106.6 & 8.75 & 4.7 \\
\hline & Field & 5.06 & 18.55 & 2.6 & 2.45 & 136.9 & 2.457 & 4.9 \\
\hline \multirow[t]{2}{*}{ L.S.D.at.01 } & Lab. & 4.97 & 44.975 & 4.5 & 6.6 & 195.8 & 20.17 & 10.8 \\
\hline & Field & 9.275 & 42.775 & 5.97 & 4.5 & 251.32 & 5.63 & 11.2 \\
\hline
\end{tabular}

$* *$ = Highly Significant $(\mathrm{p}<0.01)$

S.D. $=$ Standard deviation

L.S.D. = Least significant difference

n. $s=$ none Significant $(p>0.05)$
* Significant $(p<0.05)$

Malfo.= Malformation\%

Lab.=Laboratory strain

\subsection{Pupation and adult emergence}

Data in Tables (2 and 3)demonstrated that the treatment of the second instar larvae of both lab. and field. strains with the four tested compounds, Pyridalyl, Radical, Spinosad and Lannate, and the treatment of the fourth instar larvae of the two strains with both Pyridalyl and Radical at their LC $_{50}$ values, caused highly significant $(p<0.01)$ reduction of the pupation percentages, as compared to control . The pupation ranged from 51.7-57.7and $53-60 \%$ of the second instar for the lab. and field strains, respectively, treated with the four tested compounds , as compared to that of the check (100\% pupation of both strains). Also the treatment of the fourth instar of the lab. and field strains with both Pyridalyl and Radical caused highly significant $(p<0.01)$ decrease in the pupation to average $58,60.7$ and $59.7,62 \%$ of the second and fourth instars of both strains treated with the two compounds, 
444 COMPARATIVE TOXICITY OF THREE NOVEL BIOTIC COMPOUNDS, SPINOSAD PYRIDALYL AND

RADICAL IN RELATIVE TO A CONVENTIONAL INSECTICIDE, LANNATE AGAINST THE FIELD AND LABORATORY STRAIN OF THE SECOND AND FOURTH INSTAR LARVAE OF COTTON LEAFWORM, Spodoptera Littoralis (BOISD.)

respectively , as compared to control (100\%). However, the larval treatment of the fourth instar of lab. and field strain with Spinosad and the treatment of the field strain with Lannate induced significant $(p<0.05)$ decrease in the pupation to average $63.3,68.3$ and $64.7 \%$, respectively, as compared to control (100\%).

Data in Tables ( 2 \&3) showed that the treatment of the second and fourth instar larvae of both lab. and field strains with the four tested compounds, at their $\mathrm{LC}_{50}$ values, highly significantly $(p<0.01)$ reduced the adult emergence percentages as compared to that of the check. The adult emergence rates ranged from 52.8 to 62.7 and 60 to $66.3 \%$ for the second instar larvae of the lab. and field strains, respectively, as compared to $100 \%$ of control. In case of the fourth instar larvae, these rates ranged from $57-67$ and $72-75 \%$, as compared to that of the control (100\%).

These results are in agreement with those obtained by Ahmed (2004) who found that the average percentage of pupations and adult emergence for pink and spiny bollworms gradually decreased with increasing concentrations of the tested compounds (Agerin , Diple 2x Naturalis $L$, Spinosad) in laboratory and field strains. Similar results were obtained by Abdel- Rahim (2002) who recorded that the larval treatment of $A$. ipsilon with $A$. maritima extract induced the highest reduction in the adult emergence by a contact method, and Abo -El - Ghar et al. (1994) who demonstrated a decrease in the adult emergence of $A$.ipsilon treated as $4^{\text {th }}$ instar larvae with petroleum ether extracts of L. cylindrica, A. majus, C. elegans and $V$. rosea, as compared to control .

\subsection{The Pupal weight}

The treatment of the second instar larvae of the field strain with Pyridalyl , Radical and Lannate highly significantly $(p<0.01)$ reduced the weight of the resulting pupae to average 160,182 and $184 \mathrm{mg}$, respectively, as compared to that of control (377mg) . The treatment of second instar of the lab. strain with Pyridalyl, Radical, and the lab and field strains with Spinosad significantly $(p<0.05)$ decreased the pupal weight to 258, 262, and 267 and $264 \mathrm{mg}$, respectively , as compared to 390 and $377 \mathrm{mg}$ pupal weight of the second instar of the lab. and field strains of control. However, the larval treatment of fourth instar of both strains did not give any significant decrease in the pupal weight, as compared to control (Tables 2 and 3).

These results are similar with those obtained by Ahmed (2004) who recorded that the Spinosad, Agerin and Cascade treatments caused a significant gradual reduction in pupal weight of pink and spiny bollworms in the laboratory and field strains, while Tagetes oil was the least effective one. Adel-Rahim(2002) reported that the larval treatment of $A$. ipsilon with C. fistula , A. maritima and T. tipu extracts decreased the pupal weight of the resulting pupae. 


\subsection{Morphogenetic effects}

Data obtained (Tables2\&3) showed that the treatment of the second and fourth instars larvae of both lab. and field strains of $S$.liitoralis with Pyridalyl and Lannate induced highly significant $(p<0.01)$ increase in the pupal malformations. The average of the pupal malformation rates in the case of the second instar larvae treated with Pyridalyl were 16.7 and $15.4 \%$ of both strains, respectively, while those of the fourth instar larvae treated with the same compound were 13.2 and $10.8 \%$, respectively. While, The average of the pupal malformation rates in the case of the second instar larvae treated with Lannate were 30 and $20 \%$ of both strains, respectively, while those of the fourth instar larvae treated with the same compound were 18.7 and $16 \%$, respectively, comparing to $(0 \%)$ for the control treatment. The larval treatment of second instar of lab. strain with Radical induced significant $(p<0.05)$ increase in the pupal malformations of $8.1 \%$. While, the larval treatment of the fourth instar of both lab. and field strains and of the second instar of the field strain with Radical, as well as the treatment of the second and fourth instar larvae of lab. and field strains with Spinosad gave none significant increase in the pupal malformations, as respect to control.

With regarded to the adult malformations (Tables $2 \& 3$ ), it was found that the treatment of the second and fourth instars larvae of both lab. and field strains of $S$. liitoralis with Pyridalyl, and of the second instar of lab. strain with Radical, and of the second and fourth instars of lab. strain of with Spinosad, and of second and fourth instar of field strain with Lannate induced highly significant $(p<0.01)$ increase in the adult malformations to reach 27.3, 26.2 and 25, $22,20,25.6$ and 23.1, and $20,24.5 \%$,respectively, as compared to control $(0 \%)$. However, the treatment of the second instar of field strain and of the fourth instars of lab. strains of with Radical, and of the second instar of field strain with Spinosad, and of the second instar of the lab. strain of with Lannate caused significant $(p<0.05)$ increase in the adult malformations reached 8.1 and $8.3,10$, and 10 , respectively, as compared to control $(0 \%)$. While, the treatment of the fourth instar of the field strain with Radical and Spinosad and of lab. strain with Lannate gave none significant increase in the adult malformations, as compared to control.

These results are similar to those obtained by Ahmed (2004) who reported that Spinosad gave malformed pupal and adults in both laboratory and field strains of both Pink and Spiny bollworms and, Abdel- Rahim (2002) who indicated that $A$.maritima extract was the most potent extract in inducing noticeable malformations in both pupae and adult stages of $A$. ipsilon that treated as $4^{\text {th }}$ instar with this extract by a contact method. Also, Abo- El - Ghar et al.(1994) obtained similar results on the S.littoralis . 
Malformations of $S$.littoralis pupae resulting from the larval treatment of $2^{\text {nd }}$ and $4^{\text {th }}$ instars of both field and lab. strains with both Pyridalyl and Radical in the present work mostly appeared a malformed pre-pupa failed to cast the old cuticle with complete blackening of the body leading to death (Fig. 1,2 ), or larval-pupal monstrosity with larval cuticle patches, head capsule and thoracic legs, posterior half of the body has the pupal properties(Fig. $3,4,5$ ) or pupa with vestiture of larval skin undersized pupa(Fig. 6 ) .Moreover, moth malformations showing body with poorly developed and twisted wings(Fig. 7,8,9,10 and 11).However, the treatment of both of $2^{\text {nd }}$ and $4^{\text {th }}$ instars of field and lab. strains with Spinosad , appeared as abnormal pupae showing body shrinkage( Fig. 12 )or larval- pupal monstrosity with larval cuticle patches, head capsule and thoracic legs, posterior half of the body has the pupal properties (Fig. 13 )and the moth malformations appeared with body bear malformed twisted wings(Fig. 14,15,16).Also, the treatment of both $2^{\text {nd }}$ and $4^{\text {th }}$ instars of field and lab. strains with Lannate showed as a malformed pre-pupae with complete blackening of the body leading to death(Fig.17,18 )or larval-pupal intermediates with larval cuticle patches, head capsule and thoracic legs, posterior half of the body has the pupal properties(Fig .19) )while, the malformed adults had abnormal body and wings (Fig. 20,21,22 )as compared to normal pupae and adults (Figs. 23,24).

\subsection{Adult fecundity and fertility}

Data presented in Table (4) indicated that the treatment of the fourth instar of lab. and field strains of $S$. littoralis with Pyridalyl , and of field strains of the same instar with Radical ,Spinosad and Lannate, highly significantly $(p<0.01)$ reduced the adult fecundity to average $15,62.3,66,30$, and 80 eggs/f , respectively ,as compared to 572.3 and 294.3 eggs/f of control. However, the treatment of lab. strain of the same instar with Spinosad and Lannate, significant $(p<0.05)$ decreased the adult fecundity to average 105 and 140 eggs/f, respectively, as compared to control, while the larval treatment of the fourth instar of lab. strain with Radical gave none significant reduction in the adult fecundity , as compared to control .

Likewise, the treatment of the fourth instar of both lab. and field strains of $S$. littoralis with Pyridalyl, and of field strains of the same instar with Radical ,Spinosad and Lannate highly significantly $(p<0.01)$ reduced the adult fertility to average 4 and $43,45.7,21.3$, and 52.3 eggs/f, respectively, ,as compared to 536.3 and 283.3 eggs/f, respectively. However, the treatment of lab. strain of the same instar with Spinosad and Lannate, significant $(p<0.05)$ decreased the adult fertility to average 53 and 102 eggs/f, respectively, as compared to control( 536.3 and 283.3 eggs/f, respectively), while the larval treatment of the fourth instar of lab. strain with Radical gave none significant reduction in the adult fecundity, as compared to control . 
448 COMPARATIVE TOXICITY OF THREE NOVEL BIOTIC COMPOUNDS, SPINOSAD PYRIDALYL AND RADICAL IN RELATIVE TO A CONVENTIONAL INSECTICIDE, LANNATE AGAINST THE FIELD AND LABORATORY STRAIN OF THE SECOND AND FOURTH INSTAR LARVAE OF COTTON LEAFWORM, Spodoptera Littoralis (BOISD.)

These results are in agreement with those obtained by Pineda et al.(2007) who reported that Spinosad and methoxyfenozide reduced in a dose-dependent manner the fecundity and fertility of $S$. littoralis adult when treated oral and residually .Also, Ahmed (2004) reported that the number of eggs produced by spiny bollworm females resulting from the treated larvae with the Spinosad for laboratory and field strains larvae was decreased per female as compared with the control. He mentioned that the average $\%$ hatchability for the eggs of treated females in both strains were decreased in both of the pink and spiny bollworms as compared with control. Hashem et al.(1994) recorded a reduction in both fecundity and fertility as a result of abnormalities in the ovaries of $S$.littoralis adults fed as $4^{\text {th }}$ instar larvae on artifical diet mixed with $2 \%$ of fruit extract of $M$. azedarach for $72 \mathrm{~h}$.

Table 4. Biological activity of Pyridalyl ,Radical, Spinosad and Lannate against the adults of Spodoptera littoralis treated as $4^{\text {th }}$ instar larvae of Lab. and field strains with the $\mathrm{LC}_{50}$ values.

\begin{tabular}{|c|c|c|c|c|c|c|}
\hline \multirow[b]{2}{*}{ Treatments } & \multirow[b]{2}{*}{ Strain } & Fecundity & Fertility & Longevity & Adult sex & ratio $(\%)$ \\
\hline & & $\begin{array}{c}\text { Mean } \pm \text { S.D. } \\
(\text { eggs/f) }\end{array}$ & $\begin{array}{c}\text { Mean } \pm \text { S.D } \\
\text { (eggs/f) }\end{array}$ & $\begin{array}{c}\text { Mean } \pm \text { S.D } \\
\text { (days) }\end{array}$ & Male & Female \\
\hline \multirow[t]{2}{*}{ Pyridalyl } & Lab. & $15 \pm 5^{* *}$ & $4 \pm 2.2 * *$ & $3.3 \pm 0.8 * *$ & 58.0 & 42.0 \\
\hline & Field & $62.3 \pm 2.1 * *$ & $43 \pm 1.6 * *$ & $4 \pm 1.6^{* *}$ & 51.8 & 48.2 \\
\hline \multirow[t]{2}{*}{ Radical } & Lab. & $235+12.2 \mathrm{n} . \mathrm{s}$ & $197 \pm 2.1 \mathrm{n} . \mathrm{s}$ & $5.8 \pm 1.3^{*}$ & 55 & 45 \\
\hline & Field & $66 \pm 3.7 * *$ & $45.7 \pm 3.3 * *$ & $5.3 \pm 4.3 *$ & 46.7 & 53.3 \\
\hline \multirow[t]{2}{*}{ Spinosad } & Lab. & $105 \pm 7.3 *$ & $53 \pm 5^{*}$ & $7.3 \pm 0.4 \mathrm{n} . \mathrm{s}$ & 58.3 & 41.7 \\
\hline & Field & $30 \pm 5 * *$ & $21.3 \pm 2.1 * *$ & $6 \pm 2.1 \mathrm{n} . \mathrm{s}$ & 43.9 & 56.1 \\
\hline \multirow[t]{2}{*}{ Lannate } & Lab. & $140 \pm 8.2 *$ & $102 \pm 4.9 *$ & $5.3 \pm 1.1 *$ & 50 & 50 \\
\hline & Field & $80 \pm 5^{* *}$ & $52.3 \pm 2.1 * *$ & $5 \pm 1.2^{* *}$ & 50.6 & 49.4 \\
\hline \multirow[t]{2}{*}{ Control } & Lab. & $572.3 \pm 129$ & $536.3 \pm 113$ & $9.8 \pm 2.3$ & 50 & 50 \\
\hline & Field & $294.3 \pm 28$ & $283.3 \pm 27$ & $8.8 \pm 2.2$ & \multirow[t]{9}{*}{50} & \multirow[t]{9}{*}{50} \\
\hline \multirow[t]{2}{*}{$\mathrm{F}$ value } & Lab. & 26.701 & 30.842 & 15.5985 & & \\
\hline & Field & 163.586 & 174.3 & 35.526 & & \\
\hline \multirow[t]{2}{*}{$P$ value } & Lab. & 0.0375 & 0.0342 & 0.02956 & & \\
\hline & Field & 0.006717 & 0.00581 & 0.00945 & & \\
\hline \multirow[t]{2}{*}{ L.S.D.at.05 } & Lab. & 408.8 & 350.8 & 4.175 & & \\
\hline & Field & 81.625 & 79.655 & 2 & & \\
\hline \multirow[t]{2}{*}{ L.S.D.at.01 } & Lab. & 942.97 & 808.98 & 7.7 & & \\
\hline & Field & 188.3 & 183.71 & 3.7 & & \\
\hline
\end{tabular}

** = Highly Significant $(p<0.01)$

$*$ Significant $(p<0.05)$

S.D. $=$ Standard deviation

Malfo. $=$ Malformation $\%$

L.S.D. $=$ Least significant difference

Lab.=Laboratory strain

n. $s=$ none Significant $(p>0.05)$

\subsection{Adult longevity}

Data obtained in Table (4)showed that the treatment of the fourth instar of both field and lab. strains of $S$. littoralis with Pyridalyl, and of the field strain of the same instar with Lannate, highly significantly $(p<0.01)$ reduced the adult longevity to average 3.3 and 4.4 , and 5 days, respectively, as compared to 9.8 and 8.8 days, 
respectively, adult longevity of control. The larval treatment of the fourth instar of both lab. and field strains with Radical, and of the lab. strain of the same instar with Lannate, significantly $(p<0.05)$ decreased the adult longevity to 5.8 and 5.3 , and 5.3 days, respectively, as compared to control, whereas the treatment of the fourth instar of both lab. and field strains with Spinosad gave none significant decrease in the adult longevity to average 7.3 and 6 days, respectively .

These results are in agreement with that obtained by Abdel- Rahim(2002) who demonstrated a significant decrease in the adult longevity of $A$. ipsilon by the larval treatment of $4^{\text {th }}$ instar with $A$. maritima and $T$.tipu extracts by a contact method.

\subsection{Adult sex ratio}

Data obtained in Table (4) demonstrated that the larval treatment of the fourth instar of lab. strain with both Pyridalyl and Spinosad had the highest effect in the sex ratio shifting of adult males and females, it induced males increase and females decrease, as respect to that of control, it reached 58:42 and 58.3:41.7\%of both adult Males: females, respectively, as compared to 50:50 of control, while the treatment of the instar of the same strain with Lannate had the least effect on sex ratio, it recorded the same ratios of control (50:50\%).However, the treatment the fourth instar of field strain with Spinosad had the contract effect in adult males decrease and female increase to reach $43.9: 56.1 \%$ of both adult males: females, respectively , as compared to50:50 of control, while the treatment of the fourth instar of the same strain of the with Radical had the next effect on the sex ratio ,it reached $46.7: 53.3 \%$ of both adult males: females, respectively, as compared to control(50:50\%), while the treatment of the instar the same strain with both Pyridalyl and Lannate had the least effect, it recorded approximately ratios of that of control.

\subsection{Conclusion}

The results of the present work demonstrated that the three tested novel compounds were effective against the survival of the $2^{\text {nd }}$ and $4^{\text {th }}$ instar larvae of both susceptible and resistant strains of $S$.littoralis .Radical had the highest efficacy against the survival of the insect, while Pyridalyl had the most potent against the studied insect biology. Other investigations proved that Pyridalyl was less harmful than existing insecticides to various beneficial arthropods, so it should provide an important tool in IPM and insecticidal management programmes for the control of lepidopterous pests on cotton and vegetables, without phytotoxicity(Sakamoto et al.,2004).Also, Spinosad had an unique mode of action coupled with a high degree of activity on targeted pests and low toxicity to non-target organisms (including many beneficial arthropods).It possesses rapid efficacy competitive with the best synthetic standards and consider an excellent new tool for management of insect pests (Gary et al., 
1999).Thus these compounds were be effective if applied at the obtained lethal concentrations within the integrate control program of this pest for reduction of classic synthetic insecticides use of serious effects on the environment.

\section{REFERENCES}

1. Abbott, W. S. 1925. A method of computing the effectiveness of an insecticide .J. Econ. Entomol.,18: 265-267.

2. Abdel-Rahim, E. F. 2002. Effect of some botanical extracts and growth regulators on Agrotis ipsilon and Earias insulana .Ph.D.thesis, fac.Sci, Cairo -Univ.

3. Abo-El- Ghar ,G. E. S ., S . K. Mohamed and M. E. Tahany. 1994. Effects of

4. plant extracts on development and fecundity of Agrotis ipsilon. Bull . Ent . Soc.Egypt, 21:171-190.

5. Ahmed, E. 2004. New approaches for control of cotton bollworms. Ph.D. thesis, Faculty of Agric. Cairo Univ.

6. Cook, D. R., B. R. Leonar and J. Gore. 2004. Field and Laboratory performance of Novel insecticides against army (Lepidoptera : Noctudiae). Florida entomologist $87(4)$.

7. David, J. S., D. N.Hany and B. Mark.1996. control of black cutworm, (Hufnagel), and Sod webworms (Pyralidae:Crambinae)on creeping Bentgrass, Agrostis palustris Hudson, with Spinosad formulations Columbus,Oh,1Entomology Depart., The Ohio state University/O.A.R.D.C. Wooster, OH 44691-4096.

8. El -Defrawi, M. F., A. Toppozada, N. Mansour and M.Zaid.1964. Toxicological studies on the Egyptian cotton leafworm Prodenia litura I- Susceptibility of different larval instars of Prodenia to insecticides J .Econ. Entomol., 57:591-593.

9. Finney,D. J.1971. Probit analysis, 3rd. edition, Cambridge Univ.Press, pp.333.

10. Gary D. T., H. H. Scott and C. S. Thomas. 1999. Development of Spinosad and Attributes of a New Class of Insect Control Products. University of Minnesota.

11. Grove, J. F. H. H. S. Bovington. 2008. Thiocyanate insecticides: The relation between knock-down activity and chemical constitution .Vol. 34, Issue 1,113126.

12. Hashem, H. O., A. M. Kheirallah, M. H. Swidan and W. E. Osman. 1994. Effect of alcoholic fruit extract of Melia azedarach L. on the ovaries, fecundity and fertility of cotton leafworm moths Spodoptera littoralis (Boisd.).Alexandria J. of Agricultural-research, 39:1,211-227.

13. Hilal, A., M. G. Oktay. 2006. The Efficacy of Spinosad on Different Strains of Spodoptera littoralis (Lepidoptera: Noctuidae) Turk J Biol. Vol, 30 , pp. 5-9. 
14. Isayama, S., S. Saito , K. Kuroda, K. Umeda and K. Aamatsu. 2005. Pyridalyl, a novel insecticide: potency and insecticidal selectivity : Arch Insect Biochem Physiol. Apr,58(4):226-33.

15. Ivan, W. K. and F. E. Jesus. 2000. Spinosad battles crops pests .Agricultural research magazine.

16. Kassem, S. M. I., M. I. Aly, N. S. Bakry and M. I. Zeid. 1986. Efficacy of methomyl and its mixtures against the Egyption cotton leafworm and bollworms. Alexandria. journal.research,31:3,291-300,19 ref.

17. Moulton , J. K., D. A. Pepper and T. J. Dennehy. 1999. Studies of Resistance of Beet Armyworm (Spodoptera exigua) to Spinosad in Field Populations From the Southern USA and Southeast Asia ., Arizona university. Agriculture College.

18. Pineda, S., M. I. Schneider, G. Smagghe , A. M. Martínez, P. D. Estal , E. Viñuela, J. Valle and F. Budia. 2007. Lethal and sublethal effects of methoxyfenozide and spinosad on Spodoptera littoralis (Lepidoptera: Noctuidae). J Econ Entomol. Jun ,100 (3):773-80.

19. Sakamoto N., S. Saito T. Hirose, M. Suzuki, S. Matsuo, K. Izumi, T. Nagatomi, H. Ikegami, K. Umeda, K. Tsushima and N. Matsuo. 2004. The discovery of pyridalyl: a novel insecticidal agent for controlling lepidopterous pests. Pest Management Science, Vol, 60( 1): pp. 25-34(10)

20. Shigeru Saito, Shinji Isayama, Noriyasu Sakamoto and Kimitoshi Umeda. 2004. Insecticidal Activity of Pyridalyl: Acute and Sub-Acute Symptoms in Spodoptera litura Larvae. J. Pestic. Sci. Vol. 29, pp.372-375

21. Temarak, S. A. 2007. Suscetibility of Spodoptera littoralis to old and new generation of Spinosyn products in five cotton. Resistant pest mangament ,vol 16, No.2.

22. Temerak, S. A. 2003a. Differential susceptibility of pink bollworm ,to the ova-larvicidal activity of spinosad a natural metabolite of the Actinomycete saccharopolyspora spinosa with special reference to solve the field failure of thiodiocarb in the current resistance rotation spraying program in Egypt. Resistant Pest management ,Newsletter 13(1):427-46.

23. Thompson, G. D., R., Dutton and T. C. Sparks. 2000. Spinosad-a case study: An example from a natural products discovery programme. Pest Manage. Sci. 56, 696-702.

24. Thompson, G. D. , K. H. Michel, R. C. Yao, J. S. Mynderse, G. T. Mosburg, T.V. Worden, E. H. Chio, T. C. Sparks and S. H. Hutchins. 1997. The discovery of Saccharopolyspora spinosa and a new class of insect control products. Down to Earth 52 (1): 1-5. 


\section{مقارنة لسمية ثلاث مركبات إبادية حديثة،البيريد/ليل،الراد يكال،الأسبينوساد والمبيا التقليدي،لانيت ضد يرقات العمر الثاني والرابع للسلالة المعلية

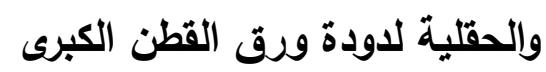

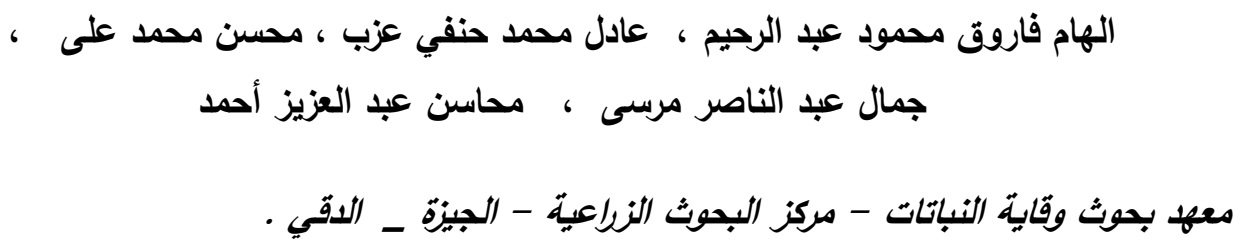

أجريت هذه الدراسة بغرض مقارنة التأثير السأم لثلاث مركبات جديدة وهى البيريداليل، الراد

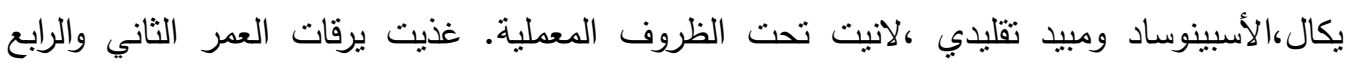

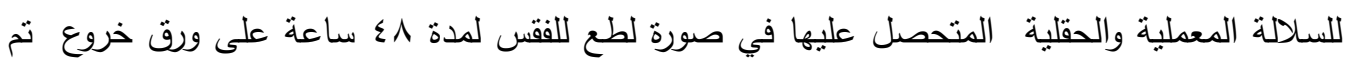

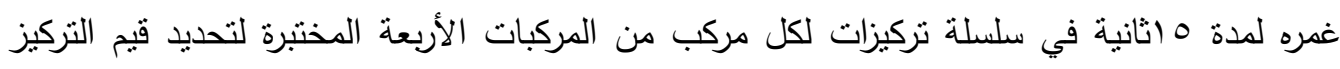

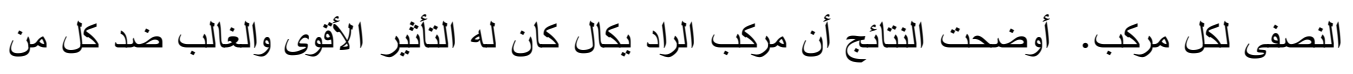

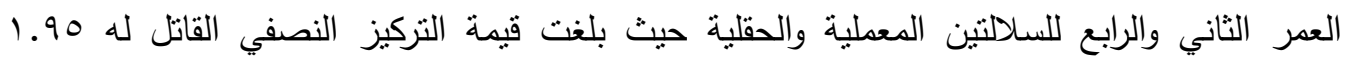

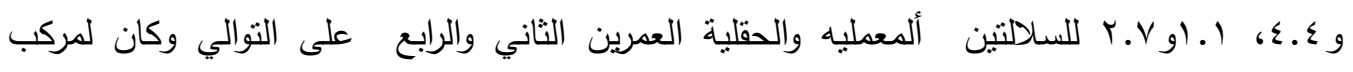

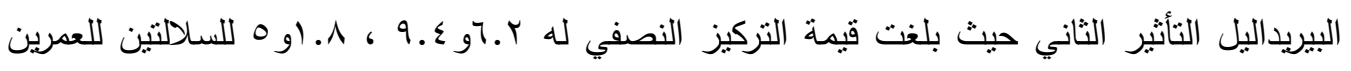

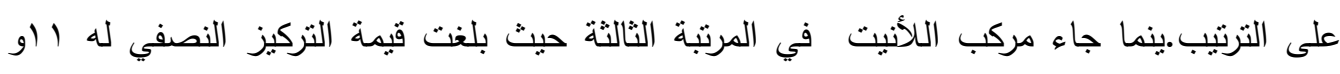

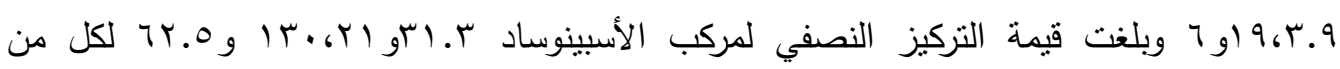

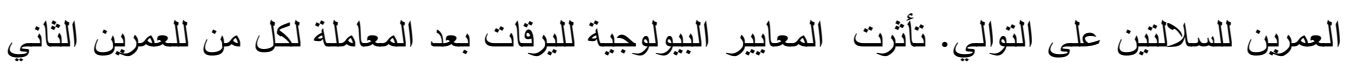

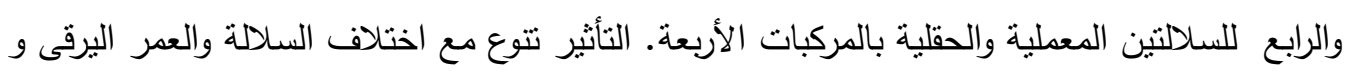

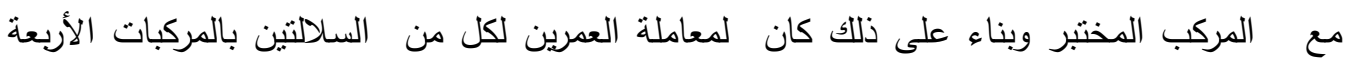

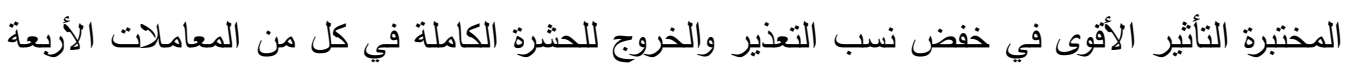

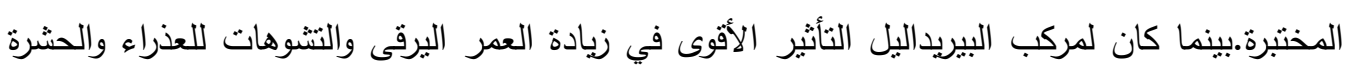

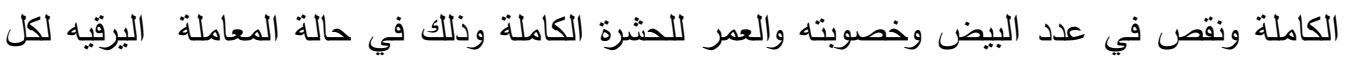

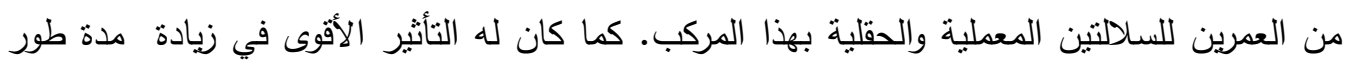

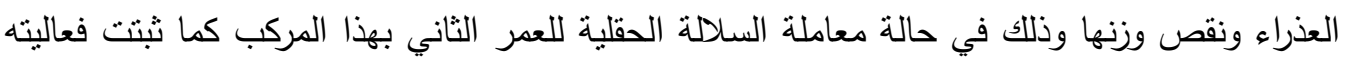

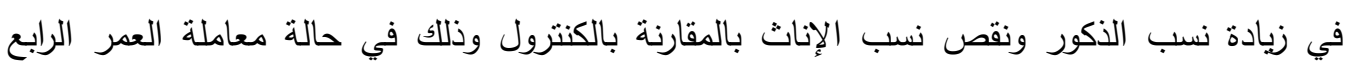

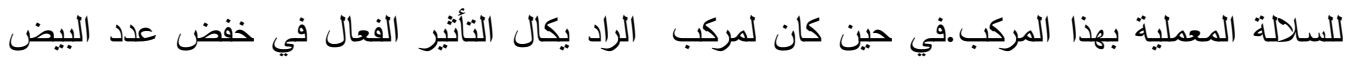

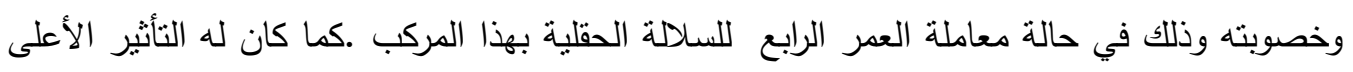

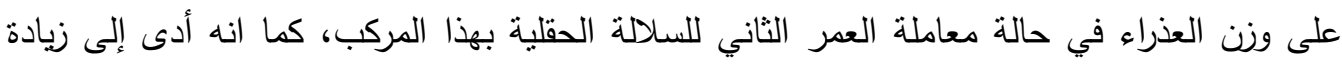

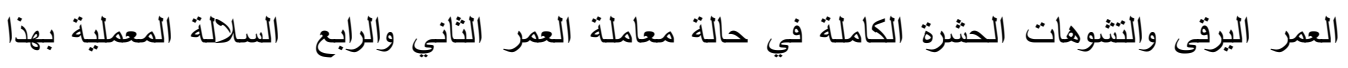
المركب وكما انه اثر في النسب الجنسية حيث أدى إلى نقص نسب النسان الذكور وزيادة في عدد الإناث 
بالنسبة للكنترول وذلك في حالة معاملة العمر الرابع للسالة الحقلية بهذا المركب ـ كما كان لمركب

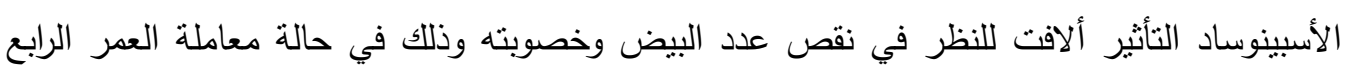
للسلالة الحقلية بهذا المركب حيث أعطى زيادة في نسب التشوهات للحشرة الكاملة وذلك في حالة معاملة العمر الثاني و الرابع بهذا المركب كما انه رفع نسب الذكور ونقص نسب الإناث وذللك في حالة معاملة العمر الرابع للسلالة المعملية بهذا المركب. في حين وجد لمركب أللانيت التأثثر الأكبر في زيادة التشوهات العذرية وذللك في حالة معاملة العمرين الثاني والرابع لكل من السلالتين بهذا المركب.وكان له التأثير الأقوى في نقص الوزن العذري وزيادة للتشوهات للحشرة الكاملة وذللك في حالة

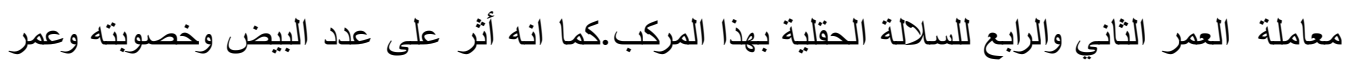

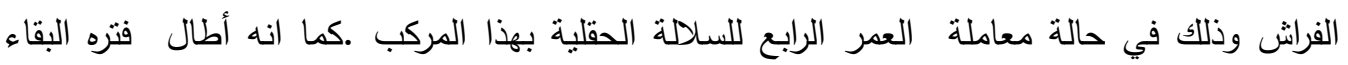
اليرقى وذلك في حالة معاملة العمر الرابع للسلالة المعلية بهذا المركب. 